International Review of Social History 43 (1998), Supplement, pp. 57-80

(C) 1998 Internationaal Instituut voor Sociale Geschiedenis

\title{
Incorporating Space into Social Histories: How Spatial Processes Operate and How We Observe Them
}

\author{
Glenn Deane, E.M. Beck and Stewart E. Tolnay
}

Social historians study social, political, demographic and economic phenomena which take place in geographical space, yet "space" rarely enters historical discourse explicitly as an analytic construct. Given the recent interest among social historians in "localizing" social processes, it is unfortunate that almost all of our efforts have gone toward recognizing the significance of time, to the relative neglect of space. 'For example, social historians typically assume that events occurring at a given point in time are affected by earlier events. In contrast, it is less widely recognized that events occurring in one location are also affected by similar events in other areas, especially those nearby. In the rare instances in which geographical space has been central, such as in Susan Watkins' treatment of western European fertility decline during the late nineteenth and early twentieth centuries, or in the evidence of the diffusion of democracy in post-war Europe that is emerging from the "Spatial and Temporal Diffusion of Democracy" project at the University of Colorado - Boulder, the payoff has been substantial. ${ }^{2}$ Such innovative approaches to historical theorizing give reason to believe that thinking of events in the past as parts of a process moving through time and across space will become more commonplace. If so, then social historians will need an effective and accessible method to account for the spatial distributions of their study phenomena.

Spatial patterning in a dependent variable (e.g. a concentration of events in a few neighboring areas) may not be, in itself, of much interest to social historians. Clearly there is a tendency for nearby, especially contiguous, areal units to share many of the same social, demographic, economic and cultural characteristics. If those characteristics tend to facilitate (or inhibit) the occurrence of the phenomenon, then, left unaccounted for, it is possible that we would infer an unusual spatial concentration of the phenomenon that can be explained easily by the social and economic similarities of adjacent areas. For instance, it is well known that urban crime within cities is

1. The importance of incorporating space and time in historical sociology is made in Larry W. Isaac, "Transforming Localities: Reflections on Time, Causality, and Narrative in Contemporary Historical Sociology", Historical Methods, 30 (1997), pp. 4-12; yet even here "space" is subordinated to "time".

2. See, for example, Susan Cotts Watkins, From Provinces Into Nations: The Demographic Integration of Western Europe, 1870-1960 (Princeton, 1991), and John O'Loughlin, Michael D. Ward, Corey L. Lofdahl, Jordin S. Cohen, David S. Brown, David Reilly, Kristian S. Gleditsch and Michael Shin, "The Diffusion of Democracy, 1946-1994", Annals of the Association of American Geographers (forthcoming, 1998). 
concentrated in certain neighborhoods. Recent interest in "hot spots" attests to the pervasiveness of this phenomenon. But it is also well known that the social and economic antecedents of crime (e.g. poverty, unemployment, unstable families) are also geographically concentrated. Is the concentration of crime indicative of a spatial process whereby criminal activity in one neighborhood affects crime in an adjacent neighborhood? Or does it simply reflect the parallel geographic concentration of the antecedents of crime? To adjudicate between these competing interpretations, it is necessary to assess the extent to which crime continues to "cluster" within certain neighborhoods after accounting for the parallel clustering within neighborhoods of the social conditions that give rise to crime. Persistent clustering may indicate a true "spatial effect" in which the occurrence of events (e.g. crime) in one locale is causally related to events in another location, independent of shared social and economic characteristics. In the context of regression analysis, this is referred to as a spatial-effects model. ${ }^{3}$

The purpose of this essay is to motivate interest in spatial-effects models among social historians. Specifically, we will: (I) describe the common conditions under which spatial dependence arises, (2) explain a procedure (using a regression approach) through which spatial dependence can be detected and dealt with, (3) offer simple interpretations of the spatial-effects term that is produced by the procedure, as well as the coefficients for the other independent variables in the presence of spatial effects, and (4) give two illustrations of spatial processes, and their treatment, in historical research.

\section{DIFFUSION, SPILLOVERS AND DETERRENCE AS SPATIAL PROCESSES}

Spatial processes may be classified according to a simple two-dimensional scheme. Along one dimension we may identify the degree to which spatial effects diffuse over time and across space. Some processes move rapidly through time and space, e.g. epidemic diseases and their "social contagion" analog, while others are much more static, simply exerting a local influence or "spillover effect". The "Tiebout Hypothesis" of voting with one's feet (i.e. moving in or moving out) in response to local public expenditures is a classic example of highly localized "spillover". "Along the other dimension, spatial effects may have a positive impact, thereby increasing the probability

3. Even if a researcher does not infer a "causal" connection between events occurring in different areas, it is necessary to take into account the spatial clustering of social and economic characteristics in order to avoid the problem of "spatial autocorrelation". By doing so, conclusions about the relationships between a dependent variable and a set of independent variables will not be compromised by the violation of fundamental assumptions required for hypothesis testing. 4. See C.M. Tiebout, "A Pure Theory of Local Expenditures", Journal of Political Economy, 64 (1956), pp. 416-424; Richard J. Cebula, "The Tiebout Hypothesis of Voting With One's Feet: A Look At Recent Evidence", Review of Regional Studies, II (1981), pp. 47-50. 
on the occurrence of like events, or a negative impact, resulting in a decreased likelihood of additional events. These dimensions are continuous and the typology produced by their intersection is one of a two-dimensional continuum where spatial effects are more or less dynamic and the strength or magnitude of these effects ranges between strong positive and strong negative.

There is a wide range of phenomena that allude to the operation of spatial processes. Diffusion processes in social history are customarily invoked to explain the impact of population contact through disease transfer and the spread of technologies, information, attitudes, beliefs and behaviors. A natural area to begin locating this imagery is in the consequences of "Old World" and "New World" population contact. Historians have amassed ample theoretical and empirical literatures on the spread of epidemic disease in "virgin populations" and considerable effort has gone into tracking the geography of epidemics in Native American populations following European contact.' But some of the earliest methodological work on diffusion concerned the spread of technological innovation. Several studies documented the diffusion of bovine artificial insemination in Sweden from the late I940s through the early I960s. More recent efforts have emphasized the spread of ideas and behaviors. We have already cited the recent scholarship on the European fertility decline in the nineteenth century and the spread of democracy in the modern world system. Social historians have also given substantial attention to the diffusion of religious group/church membership across the United States in the "Great Awakenings" of the eighteenth and nineteenth centuries and in the evangelical Protestantism movements in this century. Still other examples may be drawn from public health, crime/deviance and criminal justice as researchers in these disciplines have suggested that the rise in violent offenses in the second half of the twentieth century can be usefully regarded as a contagious social process "analogous to disease" and capable of "contagious transmission" . What is common to each of

5. For just a few representative pieces of this literature, see William H. McNeill, Plagues and Peoples (New York, 1976); Henry F. Dobyns, Their Number Become Thinned: Native American Population Dynamics in Eastern North America (Knoxville, TN, 1983); Nobel D. Cook, Born to Die: Disease and New World Conquest, 1492-1650 (Cambridge, 1998); David P. Henige, Numbers from Nowhere: The American Indian Contact Population Debate (Oklahoma City, OK, 1998).

6. On the diffusion of bovine artificial insemination, see T. Hagerstrand, Innovation Diffusion as a Spatial Process (Chicago, 1967); and Lawrence A. Brown, Edward J. Malecki and Aron N. Spector, "Adopter Categories in a Spatial Context: Alternative Explanations for an Empirical Regularity", Rural Sociology, 4I (1976), pp. 99-I18. On religious diffusion, see Roger Finke and Rodney Stark, The Churching of America, 1776-19go: Winners and Losers in Our Religious Economy (New Brunswick, NJ, 1992); Norman K. Dann, "Spatial Diffusion of a Religious Movement", Joumal for the Scientific Study of Religion, I5 (1967), pp. 351-360; Kenneth C. Land, Glenn Deane and Judith R. Blau, "Religious Pluralism and Church Membership: A Spatial Diffusion Model", American Sociological Review, s6 (199r), pp. 237-249; Judith R. Blau, Kenneth C. Land and Kent Redding, "The Expansion of Religious Affiliation: An Explanation of the Growth of Church Participation in the United States, 1850-1930", Social Science Research, 2I (1992), pp. 329-352; and 
these examples is the notion that the study phenomenon spreads across space, making the occurrence of the phenomenon in a given area more likely than one would predict based simply on the social, economic, demographic or political characteristics of the place.

Economists often describe another positive spatial process, a "spillover effect", that is less dynamic in nature. This too is a diffusion process, but it is characterized by an absence (or near absence) of movement across space over time. In other words, if we could take repeated "snapshots" of some phenomenon, the distribution across space would look the same in each snapshot. We would see geographically distributed clusters where the phenomenon occurred a lot or very little, but these clusters would be in the same place in each successive snapshot. Contrast this image with that generally evoked by contagions or epidemics. In the latter cases, the successive snapshots would show some phenomenon sweeping across space, creating new clusters in each successive snapshot. Spillovers are created when "neighbors" look to one another as they determine their appropriate behaviors, what we might call a "keeping up with the Jones' effect". Positive spillovers have been found to (partially) determine household demand for rice in Indonesia, growth rates of GNP, and county and state expenditures.?

In practice, evidence of spatial effects is found in a patterned distribution of a variable of interest, or better yet, the model errors (residuals) from a regression of this variable on a set of independent variables that are thought to be predictive of the outcome, or dependent, variable. Typically this connotes an observance of geographic clusters, for example, high values on a variable "clustered" together in a block of neighboring areal units and low values in some other block of areal units, that are indicative of diffusion from one areal unit to another, and which are independent of other, rel-

Judith R. Blau, Kenneth C. Land and Glenn Deane, "Religious Participation, Religious Diversity, and Social Conditions", Program On Non-Profit Organizations Working Paper No. I62 and Institution for Social and Policy Studies Working Paper No. 2162 (New Haven, CT, 199r), pp. I-39. In addition to the previous references to the European fertility transition, see Stewart E. Tolnay, "The Spatial Diffusion of Fertility: A Cross-Sectional Analysis of Counties in the American South, 1940", American Sociological Review, 60 (1995), pp. 299-308, for an extension to fertility decline in the American South. On the contagious transmission of violent offenses, see Colin Loftin, "Assaultive Violence as a Contagious Process", Bulletin of New York Academy of Medicine, 62 (1986), pp. 550-555; Paul C. Hollinger, Daniel Offer and Eric Ostrov, "An Epidemiologic Study of Violent Death, Population Changes, and the Potential for Prediction", American Journal of Psychiatry, 144 (1987), pp. 215-219; and Arthur Kellerman, Understanding and Preventing Violence: A Public Health Perspective (Washington, DC, 1996).

7. See respectively, Anne C. Case, "Spatial Patterns in Household Demand", Econometrica, 59 (1991), pp. 953-965; Timothy G. Conley and Ethan Ligon, "Economic Distance, Spillovers, and Growth", Working Paper University of California, Berkeley (1995); Harry H. Kelejian and Dennis P. Robinson, "A Suggested Method of Estimation for Spatial Interdependent Models with Autocorrelated Errors, and an Application to a County Expenditure Model", Papers in Regional Science, 72 (1993), pp. 297-312; Anne C. Case and Harvey S. Rosen, "Budget Spillovers and Fiscal Policy Interdependence", Journal of Public Economics, 52 (1993), pp. 285-307. 
evant, similarities among the areas. But "a patterned distribution" also implies that spatial effects can be negative. The spatial process implied here is one whereby an incident in one location is made less likely by an incident occurring in another location. In other words, the occurrence of an event in one location has a deterrent effect on future occurrences in a different location.

Although empirical illustrations of deterrent diffusion are far less common than are cases of positive spatial effects, some examples do exist. Our examination of lynchings in ten southern states in the US between I890 and I919 demonstrates the operation of deterrent "spillover". We found that a lynching in one county, net of the effect of social conditions that give rise to racial violence, induces fewer lynchings in nearby counties than we would predict if lynchings were distributed randomly. ${ }^{8}$ A recent study of population change in Chicago census tracts in the 1970 s and 1980 s provides another example of deterrent diffusion. In this spatial analysis, the threat of violent crime and its "mobility response", net out-migration, diffused from neighborhoods located in the ghetto core beginning in the 1970s. As the threat of violent crime spread out of the ghetto core, an increase in neighboring tracts triggered white population decline as whites fled to safer, more removed, neighborhoods.?

\section{HOW DO SPATIAL PROCESSES OPERATE?}

The interpretation of social diffusion relies heavily upon analogy to the spread of contagious disease in the public health literature..$^{\circ}$ The image, then, is one of a "contagion" that spreads through the contact of carriers ("infecteds") with uninfected members of the population ("susceptibles"). The spread of a contagion depends on the density of infecteds, the density of susceptibles, the extent of contact between the two groups, and the virulence of the disease (the probability that a carrier will infect a susceptible when contact is made). Additionally, a contagion will become epidemic if the diffusion exceeds a critical value, or "threshold". The threshold value is the rate at which new infections exceed removals, and the extent to which the threshold value is exceeded determines the rate of diffusion.

The model just described was proposed and formalized for the diffusion of a wide array of social behaviors as a "threshold model of collective

8. Stewart E. Tolnay, Glenn Deane and E.M. Beck. "Vicarious Violence: Spatial Effects on Southern Lynchings, 1890-1919", American Journal of Sociology, I02 (1996), pp. 788-815.

9. Jeffrey D. Morenoff and Robert J. Sampson, "Violent Crime and the Spatial Dynamics of Neighborhood Transition: Chicago, 1970-1990", Social Forces, 76 (1997), pp. 31-64.

Io. The terminology used in this paragraph is commonplace in the public health/epidemiological literature on contagious disease. For example, see Roy M. Anderson and D.J. Nokes, "Mathematical Models of Transmission and Control", Oxford Textbook of Public Health, 2nd ed. (Oxford, 1991). 
behavior"." Interpreted in this fashion, an individual's decision to adopt a technology, engage in a behavior, or adhere to a belief system depends, in part, on the behavior of other individuals. In the epidemiological literature, a contagion typically begins slowly, then accelerates rapidly until infections saturate the population-at-risk and the density of susceptibles shrinks. Thereafter, it slows and eventually falls below the critical value, at which point the epidemic collapses.

Threshold models of collective behavior include other diffusion distributions, however. Positive diffusion of social phenomena need not follow the same path as disease contagion and obviously deterrent diffusion will involve negative effects for the impact of spatial influence on a study phenomenon. While the shape of diffusion distributions may differ, each will be nonlinear and each is derived from a mixture of individual thresholds for joining. For example, the diffusion of church membership across US counties in the early twentieth century has been shown to result from strong collective behavior influence on counties with low and high church membership rates, but influence on counties with membership rates between these extremes is weak. ${ }^{12}$ In other words, the pattern of collective influence that distributed church membership was the opposite of the pattern attributed to disease contagion, but nonetheless indicates the operation of a diffusion process.

Clearly collective behavior models, and contagion models in general, unfold over time and, as such, require repeated observations at short-time intervals to map the diffusion process. Unfortunately this type of systematic, quantitative historical data is rarely, if ever, available. Thus spatial-effects models of diffusion must take a different approach. Spatial clusters, of either a dependent variable or model errors, are "snapshots" of diffusion and are interpretable if we assume that we have captured the process at a point at which it is not changing too rapidly to quantify meaningfully. ${ }^{13}$ In other words, diffusion may take place over time but it leaves its mark in the spatial dependence we observe as departures from randomness. We can then quantify this "mark" and interpret its magnitude and the direction of its effect.

II. Mark Granovetter, "Threshold Models of Collective Behavior", American Journal of Sociology, 83 (1978), pp. 1420-1443; Mark Granovetter and Roland Soong, "Threshold Models of Diffusion and Collective Behavior", The Journal of Mathematical Sociology, 9 (1983), pp. 165-180.

12. Documented in Land et al., "Religious Pluralism and Church Membership", pp. 237-249.

13. "Spillover effects" satisfy this requirement more readily than contagion effects because they do not change over time and across space as rapidly. For example, the fact that a state's spending depends on the spending of similarly situated (in terms of economic and demographic conditions) states or that a lynching in one county diminishes the demand for lynchings in neighboring counties speaks to a lack of independence among observations, rather than the rapid unfolding of a disease or social contagion. This should not suggest, however, that spillovers are any less powerful or important than contagion effects. Indeed the methods for incorporating either of these diffusion processes are the same regardless of the source of the sparial process. We can simply be more sure when dealing with spillovers that the effect we are quantifying is accurate. 


\section{SIMPLE METHODS FOR THE DETECTION AND INCORPORATION OF SPATIAL EFFECTS}

How do we know if observations in a cross-sectional sample are spatially dependent? How do we redress this dependence if it exists? The answers to both of these questions require a partitioning of the region of interest into an $\mathrm{N} \times \mathrm{N}$ matrix, where there are $\mathrm{N}$ areas in the geographic space. ${ }^{14}$ For example, a contemporary spatial analysis of contiguous US states would result in a $48 \times$ 48 matrix. How do we represent the relationship between areal units in the matrix? Probably the most common choice is the construction of an "adjacency" matrix, in which spatially adjacent areal units (where area $i$ shares a common border with area $j$ ) are assigned scores of $I$, and $O$ otherwise (including the main diagonal). Another popular choice is the inverse of the distance between the geographic centers of the areal units (again with the main diagonal set to zero). This establishes a decay function that will weigh the effect of events in geographically closer units more heavily than those in more distant units. Inverse distance matrices are particularly useful partitions of geographic space when the phenomenon of interest involves the transfer or exchange of information. Consider, for example, the recent evidence on fertility decline. It is certainly reasonable to expect that networks spreading information about the benefits of fertility control would operate locally. Fertility limitation in distant places probably went unnoticed or, at best, carried little weight in the "numeracy" of young men and women."

The choice of matrix representations is by no means limited to the two examples given here. In fact there is an infinite number of weight matrices, but some representations will be more substantively and historically compelling than others. ${ }^{16}$ For example, in their analysis of southern lynching patterns, Tolnay et al. used the inverse of cubed distance (in miles) between county centers to weigh the spatial impact of lynchings. This decay function was chosen because it closely matched an impact radius of approximately 30 miles, an area judged to cover local information networks at the turn of the century in principally rural areas. ${ }^{17}$

I4. In the language of network analysts, this matrix establishes a connection between every ego (indexed by the $i$ rows of the matrix) and every alter (indexed by the $j$ columns of the matrix) in the geographic space. Cells on the main diagonal of the square $\mathrm{N} \times \mathrm{N}$ matrix represent areal units linked to themselves. In spatial analyses, the main diagonal is always ignored.

I5. See Watkins, From Provinces Into Nations, pp. 64-70; Pollack and Watkins, "Cultural and Economic Approaches to Fertility", Pp. 482-483; Etienne van de Walle, "Fertility Transition, Conscious Choice and Numeracy", Demography, 29 (1992), pp. 487-502; Tolnay, "The Spatial Diffusion of Fertility", p. 301.

16. For a discussion of weights, see Keith Ord, "Estimation Methods for Models of Spatial Interaction", Journal of the American Statistical Association, 70 (1975), pp. I20-121; Patrick Doreian, "Estimating Linear Models with Spatially Distributed Data", in Sociological Methodology (San Francisco, 1981), pp. 362-364; and Case, "Spatial Patterns in Household Demand", p. 959.

17. Tolnay et al., "Vicarious Violence", pp. 80I-802. 
With a weight matrix in hand, statistical methods designed to answer the two questions posed at the beginning of this section are readily available and easily implemented. The most common measure of spatial autocorrelation is Moran's $I .^{18}$ The presence of spatial dependence, as indicated by a significant Moran's I, is consistent with several spatially regressive models, including the spatial-effects model we are concerned with here.

The spatial-effects regression model has been available for quite some time, but the absence of computer software hindered empirical applications of the model. ${ }^{19}$ We now have much more accessible least-squares estimators for spatial-effects models that are widely available in statistical packages such as SAS and SPSS. A detailed description of the estimators and the method of estimation is available in the articles referenced in our annotated bibliography at the end of this essay. Our goal here is simply to provide a non-technical illustration of what happens when the estimation method is applied.

The procedure involves two stages, each one requiring the regression of a dependent variable on a set of independent (predictor) variables. ${ }^{2 \circ}$ Suppose a variable of interest, say, the number of lynching incidents per county in a given decade, is regressed on a set of independent variables, representing relevant social, economic, demographic and political characteristics of those counties. For each county, we would now have an observed number of lynchings and a predicted number of lynchings:

\begin{tabular}{|c|c|c|}
\multicolumn{1}{c}{} & \multicolumn{2}{c|}{ Matrix A } \\
\cline { 2 - 3 } \multicolumn{1}{c|}{} & $\begin{array}{c}\text { Actual number of } \\
\text { lynchings }\end{array}$ & $\begin{array}{c}\text { Predicted number of } \\
\text { lynchings }\end{array}$ \\
\hline county A & 3 & 2.7 \\
\hline county B & 5 & 4.1 \\
\hline councy C & 2 & 2.2 \\
\hline$\vdots$ & $\vdots$ & $\vdots$ \\
\hline county $\mathrm{K}$ & 1 & 0.8 \\
\hline
\end{tabular}

18. P.A.P. Moran, "A Test for the Serial Independence of Residuals", Biometrika, 37 (1950), pp. 178-181. See also, A.D. Cliff and Keith Ord, Spatial Autocorrelation (London, 1973), pp. 13-15, 2933; and Doreian, "Estimating Linear Models with Spatially Distributed Data", pp. 371, 384-386. 19. See Ord, "Estimation Methods for Models of Spatial Interaction", pp. 120-126; Doreian, "Estimating Linear Models with Spatially Distributed Data", pp. 359-388.

20. See Luc Anselin, Spatial Econometrics: Methods and Models (Boston, 1988); Kenneth C. Land and Glenn Deane, "On the Large-Sample Estimation of Regression Models with Sparial- or Network-Effects Terms: A Two-Stage Least Squares Approach", in Sociological Methodology (Washington, DC, 1992), pp. 22I-248. Anselin developed two regression estimators for spatialeffects models. The most general approach, known as an "instrumental variables" two-stage least squares (2SLS) method, was developed independently by Land. 
The actual number of lynchings will be the dependent variable in the second-stage regression as well. The predicted number of lynchings is used to construct the "spatial-effects term".

Next we need a weight matrix that links areal unit $i$ to every other unit $j$. Suppose, for the sake of simplicity, that we have a geographic space that can be subdivided into only four areal units, counties $A, B, C$ and $K$, as shown above. The resulting weight matrix will be a $4 \times 4$ square with 16 cells although cells on the main diagonal will always hold zero values because a unit cannot influence itself. In this example, we will place inverse distance (in miles) between units in the off-diagonal cells. For instance, in this case, the geographic center of county $A$ is 25 miles from the center of county B; the center of county $A$ is 30 miles from the center of county $C$, and so on.

\begin{tabular}{|l|c|c|c|c|}
\cline { 2 - 5 } \multicolumn{1}{c|}{} & Matrix B \\
\hline county A & county B & county C & county K \\
\hline county B & 0 & $1 / 25$ & $1 / 30$ & $1 / 150$ \\
\hline county C & $1 / 25$ & 0 & $1 / 60$ & $1 / 200$ \\
\hline county K & $1 / 30$ & $1 / 60$ & 0 & $1 / 120$ \\
\hline
\end{tabular}

The spatial effects of all other $j$ units on unit $i$ is then given by weighting their predicted values of the dependent variables by their distance from unit $i$ and summing over the $j$ units. This "weighting" is accomplished by multiplying each $j$ predicted value (in Matrix A) by its inverse distance from unit $i$ (in Matrix B):

\begin{tabular}{|c|c|c|c|c|c|c|c|c|c|}
\hline $\begin{array}{c}\text { county } \\
\text { A }\end{array}$ & $\begin{array}{c}\text { county } \\
\text { B }\end{array}$ & county & county & & & $\begin{array}{c}\text { county } \\
\text { A }\end{array}$ & $\begin{array}{c}\text { county } \\
\text { B }\end{array}$ & county & $\begin{array}{c}\text { county } \\
\text { K }\end{array}$ \\
\hline 2.7 & 4.1 & 2.2 & 0.8 & $x$ & $\begin{array}{c}\text { county } \\
\text { A }\end{array}$ & 0 & $1 / 25$ & $1 / 30$ & $1 / 150$ \\
\hline 2.7 & 4.1 & 2.2 & 0.8 & $x$ & $\begin{array}{c}\text { county } \\
\text { B }\end{array}$ & $1 / 25$ & 0 & $1 / 60$ & $1 / 200$ \\
\hline 2.7 & 4.1 & 2.2 & 0.8 & $x$ & $\begin{array}{c}\text { county } \\
\text { C }\end{array}$ & $1 / 30$ & $1 / 60$ & 0 & $1 / 120$ \\
\hline 2.7 & 4.1 & 2.2 & 0.8 & $x$ & $\begin{array}{c}\text { county } \\
\mathrm{K}\end{array}$ & $1 / 150$ & $1 / 200$ & $1 / 120$ & 0 \\
\hline
\end{tabular}

Ind then adding the product elements in each row, resulting in a single ralue for each unit $i$ : 


\begin{tabular}{|c|c|c|c|c|c|c|c|c|c|}
\hline & $\begin{array}{c}\text { county } \\
\text { A }\end{array}$ & & $\begin{array}{c}\text { county } \\
\text { B }\end{array}$ & & $\begin{array}{c}\text { county } \\
\text { C }\end{array}$ & & $\begin{array}{l}\text { county } \\
\mathrm{K}\end{array}$ & & $\begin{array}{l}\text { lynching } \\
\text { exposure }\end{array}$ \\
\hline county A & $2.7 \times 0$ & + & $\begin{array}{l}4.1 \times \\
1 / 25\end{array}$ & + & $\begin{array}{c}2.2 \times \\
1 / 30\end{array}$ & + & $\begin{array}{l}0.8 \times \\
1 / 150\end{array}$ & $=$ & .238 \\
\hline county B & .11 & + & 0 & + & .037 & + & .0040 & $=$ & .151 \\
\hline county $\mathrm{C}$ & .090 & + & .068 & + & 0 & + & .0067 & $=$ & .323 \\
\hline county $\mathrm{K}$ & .018 & + & .021 & + & .018 & + & 0 & $=$ & .05 \\
\hline
\end{tabular}

Land and Deane refer to the spatial-effects term as a "generalized population-potential variable", acknowledging the origin of this measure in the migration research of Duncan, Cuzzort and Duncan. ${ }^{21}$ This term aptly reflects the fact that the "potential" variable summarizes the spatial effects of the variable of interest in surrounding areal units on a particular unit $i$, where the influence of each of the $j$ units is discounted by its distance from unit $i$. We label the generalized population-potential variable, "lynching exposure", in the illustration above. For example, county $C$ is "exposed" to more lynchings than county $\mathrm{K}$. Put simply, this means that, on average, the other counties that are closer to county $\mathrm{C}$ had experienced more lynchings than the counties that are closer to county $\mathrm{K}$. Once the set of lynching exposure values has been derived, they are entered as an additional independent variable in an equation predicting the actual number of lynchings experienced by each county. The regression coefficient computed for the lynching exposure variable is referred to as the "spatial-effects term".

\section{INTERPRETING EFFECTS IN A SPATIAL REGRESSION MODEL}

The interpretation of effects in a spatial regression model differs from that encountered in an ordinary linear and additive regression model. Spatial regression models are interaction models. The presence of the spatial-effects term in a spatial regression model renders a single value for the effect of an independent variable on the dependent variable somewhat of an oversimplification. By rewriting the spatial regression model, it can be easily shown that the spatial-effects term conditions (i.e. establishes an interaction, or multiplicative, effect on) the effects of other independent variables. ${ }^{22}$ Thus a change in an independent variable in areal unit $j$ affects the dependent variable in unit $j$, which in turn affects the dependent variable in neighbor-

21. Land and Deane, "On the Large-Sample Estimation", pp. 236-238; Otis Dudley Duncan, Ray P. Cuzzort and Beverly Duncan, Statistical Geography (Glencoe, IL, 196I).

22. See Case, "Spatial Patterns in Household Demand", pp. 955-956. 
ing units. Therefore, a dependent variable in unit $i$ changes both because of change in the explanatory variables and change in its neighbors' dependent variable. These interaction effects are captured by the spatial-effects term and vary across areal units (as will be demonstrated below).

From an interpretive standpoint, this accomplishes exactly the "localizing" of historical process that has been recently asked of historical sociologists. ${ }^{23}$ In practice, the product of this interaction between the spatialeffects term and an independent variable allows the effect of a change in an independent variable on the dependent variable to be unit specific and, as with nonlinear effects in general, no single estimate is sufficient to describe the effect of an independent variable throughout its entire range. ${ }^{24}$ In these circumstances, it is preferable either to graph the (nonlinear) effect or illustrate the range of the effect, usually by selecting (at least) a low, middle and high value from the range of effects.

\section{THE DIFFUSION OF RELIGION AND THE DETERRENCE} OF LYNCHINGS: TWO ILLUSTRATIONS

To illustrate the contribution of spatial-effects models to social history, we present two examples that incorporate features of the typology developed above. The first example comes from the remarkable expansion of church nembership early in the twentieth century in the United States. In this example, the diffusion process captured in the statistical analysis is positive and moving rapidly across geographic space. The second illustration extends the research of Tolnay and Beck on the causes of lynchings in the American jouth during the late nineteenth and early twentieth centuries. ${ }^{25}$ The spatial srocess in this study is negative and interpreted as an areal spillover. Together, these examples incorporate all the aspects of spatial processes we ave discussed in this essay.

\section{Example I: religious pluralism and church membership}

Historians of American religion now agree that rates of church membership lave risen dramatically since the eighteenth century. In The Churching of America, Roger Finke and Rodney Stark provide empirical documentation sf the growth in American religious adherence, setting the colonial adherince rate at 17 per cent and the current rate at over 60 per cent. ${ }^{26}$ Most

:3. Isaac, "Transforming Localities", p. 5.

4. The "product of this interaction" to which we refer is not the usual product term one solves n ordinary least-squares regressions. For details, see Case, "Spatial Patterns in Household Jemand", pp. 955-957.

5. Tolnay et al., "Vicarious Violence", pp. 788-815. See also Stewart E. Tolnay and E.M. Beck,

1 Festival of Violence: An Analysis of Southern Lynchings, 1882-1930 (Urbana, 1995).

6. Finke and Stark, The Churching of America, pp. I5-16. 
church historians link the expansion of religious adherence to periodic "eruptions" of religious excitement, citing the occurrences of "Great Awakenings" in the second quarter of the eighteenth century and again in the first quarter of the nineteenth century, the ascendence of the Baptists in the early twentieth century, and the "explosion" of evangelical Protestantism in general since the 1970s. Other historians of religion challenge the accuracy of this imagery of "eruptions" and "explosions", preferring the more mundane notion of "religious economies" comprised of denominational competition with an organizational life course of growth, decline and periodic attempts to revive enthusiasm. ${ }^{27}$ But whether the history of growth in American religious adherence was one of "eruptions" or "economies", the source of this expansion was the same: revivalism.

\section{Revivalism}

This has been an active and mobile enterprise in America since the exploits of the first great revivalist, George Whitefield, in the 173 os and 1740 . The importance of revivals in the expansion of religious adherence, and the way in which they are carried out, has changed little since Whitefield's campaigns. ${ }^{28}$ For hundreds of years, revivalists have traversed the country, stopping in urban centers even more often than in the rural frontier, spreading their message of faith, community and "brotherly" love. It should come as no surprise, then, that church membership rates retain the mark of geographic diffusion.

Using the religious censuses of 1906, 1916 and 1926 for all US counties and the spatial-effects model we describe here, Land and Blau provide the first compelling empirical documentation of this process. ${ }^{29}$ Their spatial analyses clearly establish the impact of a county's religious surroundings on its own rate of church adherence and Granovetter's model of collective influence frames the theoretical interpretation of this evidence.

\section{Data and variables}

Aggregate church membership data from the 1906, 1916 and 1926 Censuses of Religious Bodies are available for all US counties. For the sake of consistency with their independent variables, Land et al. relate these religious

27. For a summary of these positions, see ibid., pp. 87-92.

28. For a summary of Whitefield's tactics, see ibid., pp. 88-89; and Frank Lambert, "Pedlar in Divinity': George Whitefield and the Great Awakening, 1737-1745", Journal of American History, 77 (1990), pp. 812-837.

29. Land et al., "Religious Pluralism and Church Membership", pp. 237-249. See also Land and Deane, "On the Large-Sample Estimation of Regression Models", pp. 221-248; Blau et al., "Religious Participation, Religious Diversity, and Social Conditions", pp. I-39; Blau et al., "The Expansion of Religious Affiliation", pp. 329-352. 
censuses to the decennial US census dates of I910, I920 and 1930. Although their analyses are not longitudinal, a historical county template is used to aggregate counties involved in boundary changes during the study period into approximately $\mathrm{I}, 600$ county groups. ${ }^{30} \mathrm{~A}$ 50 per cent random sample of counties stratified by percentage urban formed the initial study sample, while the remaining 50 per cent was used to assess the robustness of their conclusions in replicate analyses.

The dependent variable was defined as a church adherence rate, the number of church members divided by county population (multiplied by I0O). In addition to the spatial-effects term, church adherence potential, seven independent variables were considered. Following the literature on the full set of social forces thought to affect church membership, explanatory variables included percentage Catholic, religious diversity, percentage change in population, ethnic diversity (using approximately 40 ethnic-origin categories available in the 1910, 1920 and 1930 decennial censuses), percentage, urban percentage illiterate and economic well-being (average manufacturing wages in county in 1920 and 1930, and average crop value in 1910).

\section{Observing diffusion}

Land et al. estimate their spatial-effects models (for I910, 1920 and 1930) using a two-stage procedure similar to the method described above. Elements of the weight matrix used in these models are measured as inverse distance, in miles, from county (or county-group) centers. In the secondstage regressions, church adherence rate is regressed on the set of relevant independent variables described above and church adherence potential. These regressions are shown in Table I. The effect of church adherence potential, the model's spatial-effects term, is positive and significant in all three decades (.33 in 1910; .29 in 1920; and .28 in 1930). Substantively, this means that counties that are surrounded by counties with high rates of church membership will tend to have high membership rates themselves. Statistizally, this means that a one point increase in church adherence potential increases a county's church membership rate by about a third of a point 'and a ten point increase in adherence potential increases a county's membership rate by about three points, and so on).

The importance of church adherence potential is highlighted if one compares these results with regressions in which church adherence potential is excluded: $R^{2}$, a summary measure of the proportion of variance in the dependent variable explained by the independent variables, declines from 52 to .38 , from .49 to .39 , and from .49 to .39 for 1910 , 1920 and 1930 espectively. Clearly, spatial diffusion is a powerful and significant compo-

;o. Patrick M. Horan and Peggy G. Hargis, "The County Longitudinal Template", Paper preented at the Annual Meeting of the Social Science History Association, Chicago, 1989. 
Table I. Second-stage least squares coefficients: church adherence rate on church adherence potential and selected independent variables for US counties, Igro, 1920, 1930 ( $t$-ratios in parentheses)

\begin{tabular}{lccc}
\hline Independent variable & 1910 & 1920 & 1930 \\
\hline Intercept & $31.47^{* * *}$ & $50.84^{* * *}$ & $54.26^{* * *}$ \\
Religious diversity index & $(5.75)$ & $(12.24)$ & $(11.73)$ \\
& $-22.67^{* * *}$ & $-28.39^{* * *}$ & $-35.56^{* * *}$ \\
Percentage Catholic & $(-9.96)$ & $(-9.21)$ & $(-10.12)$ \\
& $.36^{* * *}$ & $.28^{* * *}$ & $.28^{* * *}$ \\
Percentage change in & $(10.55)$ & $(7.53)$ & $(7.33)$ \\
population & $-1.91^{* * *}$ & $-12.58^{* * *}$ & $-15.23^{* * *}$ \\
Church adherence potential & $(-5.06)$ & $(-6.03)$ & $(-7.10)$ \\
Ethnic diversity index & $(12.66)$ & $(10.93)$ & $(10.54)$ \\
& $-11.97^{* * *}$ & $-15.17^{* * *}$ & $-8.40^{* * *}$ \\
Percentage urban & $(-4.76)$ & $(-5.18)$ & $(-2.54)$ \\
& $.04^{* *}$ & .00 & .03 \\
Percentage illiterate $(\log )$ & $(2.92)$ & $(.24)$ & $(1.52)$ \\
& $2.27^{* * *}$ & $1.99^{* * *}$ & $1.46^{* * *}$ \\
Economic well-being $(\log )^{2}$ & $(6.51)$ & $(5.46)$ & $(3.77)$ \\
& $(.13$ & $-1.22^{* * *}$ & $-.95^{*}$ \\
$\mathrm{~N}$ & & $(-3.33)$ & $(-2.53)$ \\
$\mathrm{R}^{2}$ & $731)$ & 697 & \\
\hline
\end{tabular}

Notes:

${ }^{*} \mathrm{p}<.05{ }^{* *} \mathrm{p}<.01 \quad{ }^{* * *} \mathrm{p}<.001$

${ }^{a}$ For 1910 , average crop value; for 1920 and 1930 , average manufacturing wages.

nent of church adherence early in the twentieth century, although the effect of church adherence potential declines slightly from I910 to I930 suggesting that the choice of whether to be a member of an organized religious body became increasingly independent of collective behavior influences over time.

Figure I shows a scatterplot of church adherence rates (on the vertical axis) against church adherence potential (on the horizontal axis) for I9IO. ${ }^{31}$ As expected, the relationship is indeed nonlinear. Scatters of the type shown in Figure $I$ are perhaps the best evidence available of spatial diffusion because the "best-fitting" line through this scatter (also shown in Figure I) recalls the segments symptomatic of the collective behavior (contagion) process we discussed earlier. The shape of the scatter is indicative of a bimodal frequency distribution of thresholds for church membership in the population, with a strong collective influence at the low end of the distribution of church membership (indicated by the steep slope of the polynomial near the origin) followed by a lower level of influence in the middle part of the

3I. Results for 1920 and 1930 were practically identical. 


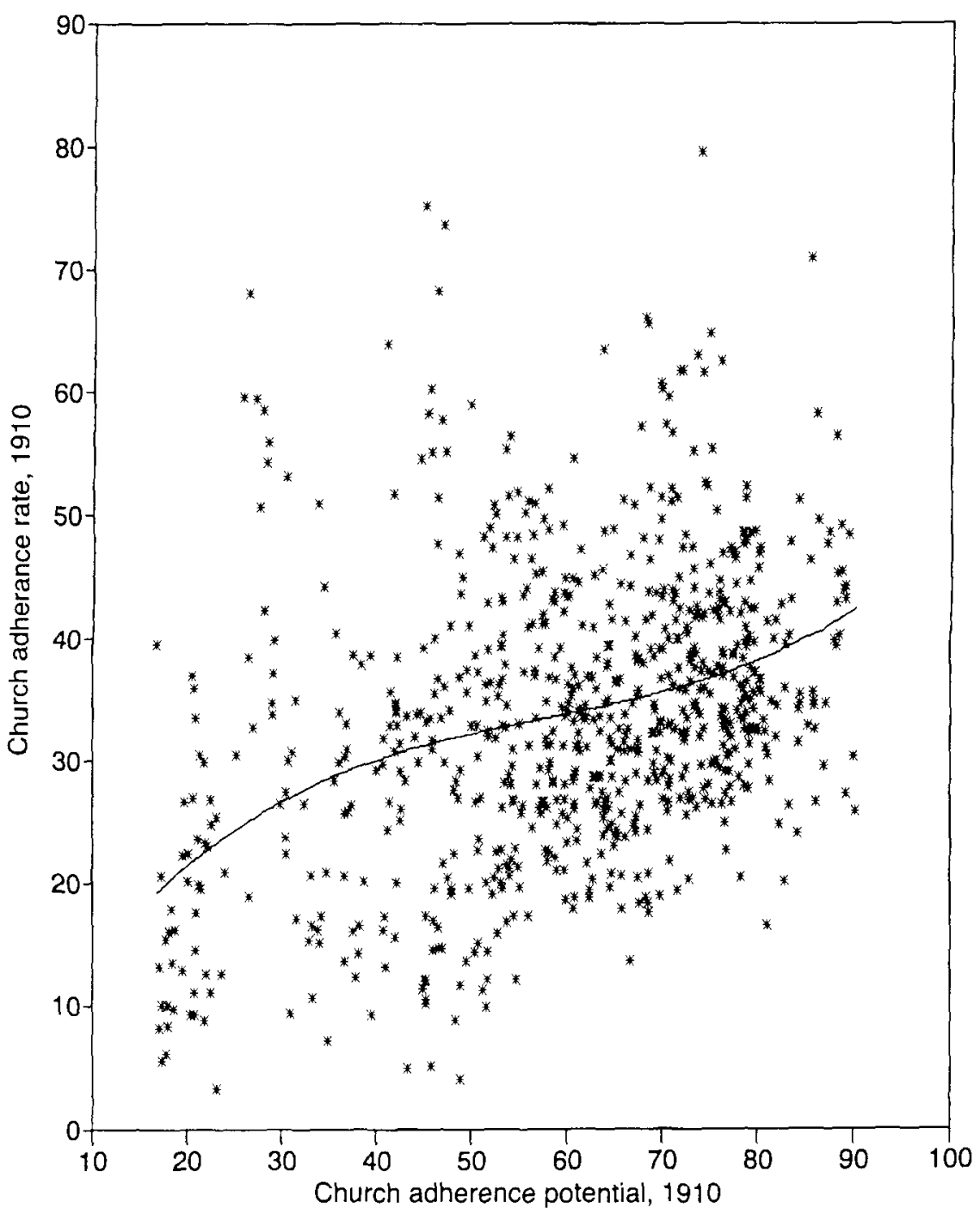

Figure I. Relationship between church adherence rate and adherence potential

curve (indicated by the "flatter" slope in the middle of the curve) and then another high collective influence region at the upper end of the scatter (shown by the increasing slope of the line). ${ }^{32}$

Although the motivations of actors can only be inferred from aggregate and cross-sectional data, the pattern shown in Figure $I$ is consistent with

32. See Land et al., "Religious Pluralism and Church Membership", pp. 24I-242. 
the history of revivalism and fully anticipated by Granovetter's theory of collective influence. This history recounts the travels of revivalists through regions with low rates of church membership as they "awakened" a religious spirit in the people of these regions. The other principal destination was to revisit regions with already high rates of adherence in an effort to maintain or rekindle spiritual enthusiasm. In terms of social contagion, the theory of collective influence predicts that counties with low rates of church membership will be highly susceptible to conversion simply because their populations are "at high risk", while counties with (relatively) high rates of adherence will be vulnerable to strong imitative/conformity processes when surrounded by other counties with high adherence rates.

\section{Example 2: vicarious violence in the American South, I890-I9I9}

The history of race relations in the American South during the late nineteenth and early twentieth centuries is a violent one. In addition to frequent beatings, whippings and verbal assaults, southern blacks faced the very real possibility of death at the hands of white lynch mobs. Recent scholarship has provided strong evidence that racial violence was one mechanism used by the white population to perpetuate its social, economic and political domination of southern society. ${ }^{33}$ The lynching, these authors argue, was a form of state tolerated terrorism aimed at the black community to preserve white hegemony and maintain the caste boundary. That lynchings were tolerated by the state and sometimes even sanctioned is suggested by the extremely low probability of arrest, prosecution and conviction of mob members - despite the fact that they were often well known to authorities.

The terroristic function of lynchings, coupled with relatively efficient avenues of communication regarding lynchings that had occurred, raise the interesting possibility that incidents of white-on-black violence across regions of the South were not independent of one another. Virtually all of the evidence for spatial processes has demonstrated - as did our first example - that a characteristic or event in one location is made more likely by the same characteristic or event in another location. As we have pointed out, however, positive diffusion is not the only type of spatial process that could have been operating. Indeed, the spatial-effects regressions of Tolnay et al. show that a lynching incident in one county actually decreased the

33. See for example, Edward L. Ayers, Vengeance and Justice: Crime and Punishment in the rothCentury American South (New York, 1984); Beck and Tolnay, "The Killing Fields of the Deep South", pp. 526-539; W. Fitzhugh Brundage, Lynching in the New South: Georgia and Virginia, 1880-1930 (Urbana, 1993); Jay Corzine, Lin Corzine and James Creech, "The Tenant Labor Market and Lynching in the South: A Test of Split Labor Market Theory", Sociological Inquiry, 58 (1988), pp. 26I-278; Herbert Shapiro, White Violence and Black Response: From Reconstruction to Montgomery (Amherst, 1988); Tolnay and Beck, "Racial Violence and Black Migration in the South", pp. I03-II6; Tolnay and Beck, $A$ Festival of Violence. 
likelihood of an incident in nearby counties - net of other factors related to the frequency of lynching. There are two primary processes through which "negative spatial effects" may have operated, both of which assume the use of lynchings as a form of terroristic social control over southern blacks. The first emphasizes the reactions of whites; the second focuses on the responses of the African-American community.

It is clear from the way that lynchings were conducted that one of their important terroristic functions was to send a "message" to the black community. That message was to warn blacks not to expect more from southern society than whites were willing to give. Based on these efforts to publicize lynchings, one must conclude that southern whites believed strongly in the general deterrent effect of lynchings. That is, by punishing a single offender, they believed that they could discourage similar offenses by others. While many southern whites agreed that lynchings could be useful for keeping local African-Americans in their place, perhaps the same effect was accomplished when lynchings occurred elsewhere, especially in neighboring areas. Other things being equal, if local blacks made a special effort to avoid antagonizing the white community - in response to a nearby lynching then the likelihood of a lynching in their own community may have been attenuated. ${ }^{34}$ Even if nearby lynchings had little impact on the behavior of local blacks, the motivation for mob action may have been reduced if whites were convinced of the deterrent effect of lynchings. An even more sinister, and less utilitarian, possibility is that lynchings in other areas satisfied a certain "bloodlust" among local whites, thereby reducing their urge to lynch.

Unlike the more common "positive contagion/diffusion effect" illustrated by our previous empirical example, a "negative spillover effect" for lynching describes a process whereby an incident in one location is made less likely by an incident occurring in a neighboring location. The result of such a process would be a negative correlation in the frequency of lynchings across nearby counties suggesting a "satisfied" white population, an intimidated black population, or both causal mechanisms.

\section{Data and variables}

Information for lynching incidents is drawn from a new inventory of southern lynchings in which each event was verified through stories carried in contemporary southern newspapers. ${ }^{35}$ The number of lynching incidents that

34. This speculation is not meant to imply that all southern blacks cowered in response to violent threats from the white community. There were many instances in which blacks offered strong resistance to lynch mobs (cf. W. Fitzhugh Brundage, "The Darien 'Insurrection' of I899: Black Protest During the Nadir of Race Relations", Georgia Historical Quarterly, 74 (1990), pp. 234-253; Shapiro, White Violence and Black Response, though the result of such resistance was often intensified bloodshed.

35. For additional information about this lynching inventory and how it was constructed, see Tolnay and Beck, A Festival of Violence. 
claimed at least one black victim is used because the type of spatial processes described above were more likely to be triggered by the mere occurrence of lynching events, rather than the number of victims claimed in each event, or the rate of victimization. Incidents are further restricted to those that were conducted by a white mob. Lynching incidents are aggregated to a county-level for ten southern states and, like the Land et al. study, county groups are created when a county's boundaries changed during a decade.

Separate spatial-effects models are estimated for three time periods during the "lynching era": 1895-1899, 1905-1909 and 1915-1919. ${ }^{36}$ The second half of each of three decades (1890-1899, I900-1909 and 1910-1919) is analyzed in order to allow for the inclusion of lagged effects in the models. The spatial-effects term in this analysis, therefore, refers to lynching incidents that occurred during the previous five-year period - for example, incidents in $1890-1894$ are used to construct the spatial-effects term for lynchings in 1895-1899. The other explanatory variables can be grouped into four different categories: demographic, socioeconomic and cultural, lynching history, and geographic. ${ }^{37}$

\section{The evidence of deterrence}

As in our previous example, Tolnay et al. employ the two-stage procedure we described. The representation of distance in a weight matrix, however, has many possibilities. Tolnay et al. use a cubic transformation of distance (measured in miles) to construct their measure of lynching exposure because auxiliary analyses showed this closely matched an adjacency matrix in which a 30-mile radius from county centers formed the adjacency criterion, but with a smoother decay function. ${ }^{38}$ Table 2 presents the findings obtained from estimation of the second-stage regression. Two models are reported for each decade. Model I is a bivariate equation that includes only lynching exposure, the spatial-effects term, as a predictor. Model 2 is the full equation,

36. This aggregation resulted in 783,779 and 770 counties/county clusters for $1895-1899$, 19051909 and 1915-1919, respectively from the ten states of Alabama, Arkansas, Florida, Georgia, Kentucky, Louisiana, Mississippi, North Carolina, South Carolina and Tennessee.

37. The relative size of the black population within each county, measured as percentage black and percentage black squared, represents the demographic controls. Two direct measures of the socioeconomic and cultural characteristics of counties, the proportion of white farmers who were tenants (again, both linear and squared terms are included) and the proportion of "improved acres" in the county that was planted in cotton are also controlled. Cross-county variation in the general reliance on lethal punishment is represented by the number of lynching incidents with white victims during the previous five years and the number of lynching incidents with black victims during the previous five years. Finally, the geographic location of counties, and the selectivity this may represent, is also incorporated into the statistical controls through a set of dummy variables measuring proximity to border states. For details on the data used to construct these independent variables, see Tolnay et al., "Vicarious Violence", pp. 802-804.

38. See ibid., pp. 801-802. 
Table 2. Second-stage least squares coefficients: number of lynching incidents on lynching exposure and selected independent variables for US counties, I8951899, 1905-1909, 1915-1919 (standard errors in parentheses)

\begin{tabular}{|c|c|c|c|c|c|c|}
\hline & \multicolumn{2}{|c|}{ 1895-1899 } & \multicolumn{2}{|c|}{ 1905-1909 } & \multicolumn{2}{|c|}{$1915-1919$} \\
\hline & Model 1 & Model 2 & Model 1 & Model 2 & Model 1 & Model 2 \\
\hline \multicolumn{7}{|l|}{ Spatial-effects term } \\
\hline Lynching exposure & $\begin{array}{l}.333 \\
(.349)\end{array}$ & $\begin{array}{l}-.983^{* *} \\
(.437)\end{array}$ & $\begin{array}{l}.458 \\
(.435)\end{array}$ & $\begin{array}{c}-2.406^{* * *} \\
(.580)\end{array}$ & $\begin{array}{l}1.728^{* * *} \\
(.325)\end{array}$ & $\begin{array}{l}-.768^{*} \\
(.449)\end{array}$ \\
\hline \multicolumn{7}{|l|}{ Demographic controls } \\
\hline$\%$ Black & & $\begin{array}{l}.095^{* * *} \\
(.026)\end{array}$ & & $\begin{array}{l}.115^{* * *} \\
(.023)\end{array}$ & & $\begin{array}{l}.122^{* * *} \\
(.016)\end{array}$ \\
\hline$\%$ Black $^{2}$ & & $\begin{array}{l}-.0009^{* * *} \\
(.0003)\end{array}$ & & $\begin{array}{l}-.0008^{* * *} \\
(.0002)\end{array}$ & & $\begin{array}{l}-.001^{* * *} \\
(.0002)\end{array}$ \\
\hline \multicolumn{7}{|c|}{$\begin{array}{l}\text { Socioeconomic and cultural } \\
\text { controls }\end{array}$} \\
\hline$\%$ White tenants & & $\begin{array}{l}.060^{* *} \\
(.029)\end{array}$ & & $\begin{array}{l}-.095^{* * *} \\
(.024)\end{array}$ & & $\begin{array}{l}-.028 \\
(.023)\end{array}$ \\
\hline$\%$ White tenants ${ }^{2}$ & & $\begin{array}{r}-.001^{* *} \\
(.0005)\end{array}$ & & $\begin{array}{l}.001^{* * *} \\
(.0003)\end{array}$ & & $\begin{array}{l}.0003 \\
(.0003)\end{array}$ \\
\hline Cotton dominance & & $\begin{array}{l}.024^{* * *} \\
(.008)\end{array}$ & & $\begin{array}{l}.044^{* * *} \\
(.011)\end{array}$ & & $\begin{array}{l}.026^{* *} \\
(.011)\end{array}$ \\
\hline \multicolumn{7}{|l|}{$\begin{array}{l}\text { Lynching history } \\
\text { controls }\end{array}$} \\
\hline $\begin{array}{l}\text { Prior black } \\
\text { lynchings }\end{array}$ & & $\begin{array}{l}-1.519 \\
(1.060)\end{array}$ & & $\begin{array}{l}-3.057^{* *} \\
(1.507)\end{array}$ & & $\begin{array}{r}-1.083 \\
(.837)\end{array}$ \\
\hline $\begin{array}{l}\text { Prior white } \\
\text { lynchings }\end{array}$ & & $\begin{array}{l}.257 \\
(.278)\end{array}$ & & $\begin{array}{l}.992^{* * *} \\
(.335)\end{array}$ & & $\begin{array}{l}1.716^{* * *} \\
(.542)\end{array}$ \\
\hline \multicolumn{7}{|l|}{ Geographic controls } \\
\hline Borders north & & $\begin{array}{l}.070 \\
(.516)\end{array}$ & & $\begin{array}{l}.000^{2} \\
(.470)\end{array}$ & & $\begin{array}{l}1.173^{*} \\
(.628)\end{array}$ \\
\hline Borders south & & $\begin{array}{l}-.426 \\
(.343)\end{array}$ & & $\begin{array}{l}.067 \\
(.344)\end{array}$ & & $\begin{array}{l}.590 \\
(.382)\end{array}$ \\
\hline Scale & 1.041 & .985 & .955 & .853 & .901 & .813 \\
\hline Intercept & $\begin{array}{l}-1.162^{* * *} \\
(.112)\end{array}$ & $\begin{array}{l}-3.126^{* * *} \\
(.502)\end{array}$ & $\begin{array}{l}-1.501^{* * *} \\
(.116)\end{array}$ & $\begin{array}{l}-1.786^{* * *} \\
(.445)\end{array}$ & $\begin{array}{l}-1.803^{* * *} \\
(.096)\end{array}$ & $\begin{array}{l}-4.104^{* * *} \\
(.508)\end{array}$ \\
\hline Pseudo $\mathrm{R}^{2}$ & .001 & .115 & .001 & .214 & .029 & .217 \\
\hline
\end{tabular}

Notes:

${ }^{2}$ Coefficient and standard error have been divided by 100,000 to adjust the scale.

* $\mathrm{p}<.10{ }^{* *} \mathrm{p}<.0{ }^{* * *} \mathrm{p}<$.OI.

with all predictor variables. This presentation format is used so that the impact of the control variables on the effect of lynching exposure can be assessed. Our primary interest in Model 2 is in the direction and strength of the effect of lynching exposure.

Looking first at Model I, for all three decades we find that lynching exposure has a positive bivariate effect on the observed number of lynching 
incidents - for the 1915-1919 period the coefficient attains statistical significance. Thus the results for Model I would lead us to believe that lynchings were either insensitive to events in other areas, or more frequent in counties that were surrounded by other counties that had a large number of incidents. However, such a conclusion would be premature. As mentioned earlier, the "clustering" of high lynching counties in the same general area may have been due to shared social, economic or cultural characteristics that created an atmosphere conducive to the lynching of blacks, rather than the operation of a spatial process distributing lynching incidents (independent of these social, economic and cultural characteristics). The primary purpose of the control variables added in Model 2 is to take into consideration those potentially shared characteristics, thereby isolating spatial process as an independent phenomenon.

Indeed, the findings obtained from Model 2 are substantially different from those observed for Model I. In all three decades the coefficient for lynching exposure reverses sign, and becomes significantly negative (at least at the $\mathrm{p}<. \mathrm{I}$ level). Net of all other variables in the model, the spatial-effects terms in Table 2 provide strong support for a "deterrence" process. That is, more intensive lynching activity in surrounding areas actually decreased the frequency of lynching incidents in these ten southern states.

\section{"LOCALIZING" HISTORY: COUNTY-SPECIFIC PREDICTORS OF LYNCHING}

The spatial-effects model is an interaction model. The presence of the spatialeffects term, lynching exposure, implies that the effects of the independent variables are county-specific. The single estimates reported in Table 2 summarize these effects, but they may be quite misleading for any given county. A more accurate representation, one that truly "localizes" the spatial process, is given by unit-specific plots of effects. Figure 2 plots the county-specific effect of cotton dominance (one of the social or economic conditions that is related to the frequency of lynching in southern counties) using Model 2 from the 1895-1899 regression in Table 2 as our example.

The effect of cotton dominance on lynching incidents in this model is 0.024 , indicating that a greater reliance on cotton agriculture increases the likelihood of lynchings. This is consistent with several intersecting hypotheses linking cotton agriculture to lynchings, including a racist ideology inherited from slavery, demand for labor control over the heavily African-American labor force, and economic competition between African Americans and poor whites. ${ }^{39}$ The horizontal pattern in Figure 2 shows that indeed most counties

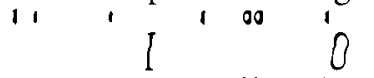

are at or near this estimated effect, but in a spatial-effects model the effect of cotton dominance on lynching incidents is conditioned by neighboring

39. See, for cxample, Tolnay and Beck, A Festival of Violence, ch. 5 . 


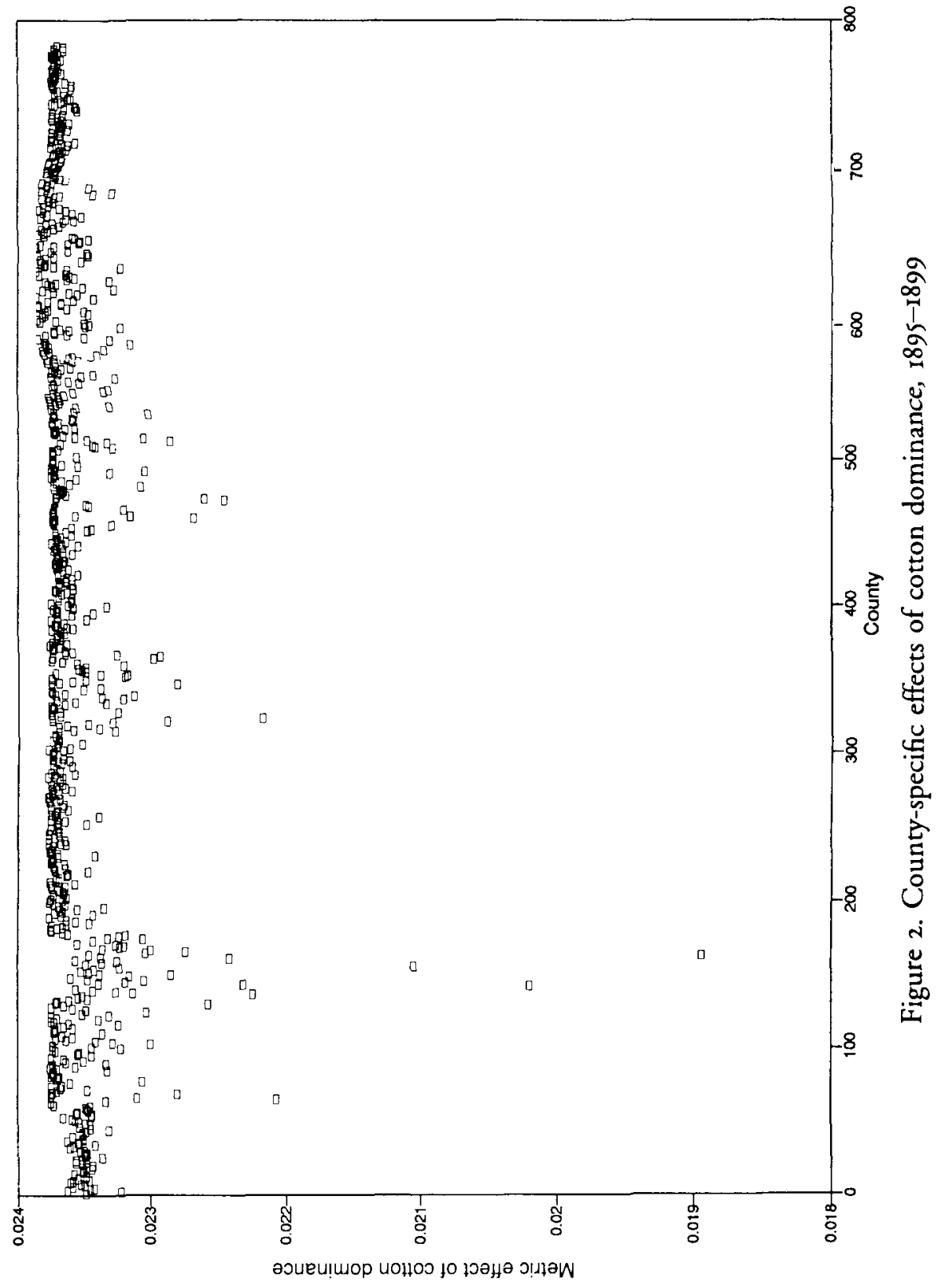


counties' lynching incidents. Indeed, some of the counties' cotton dominance effects are substantially lower than 0.024 and can be seen in Figure 2 to fall away from this line. The three most extreme departures from the horizontal pattern are Marion, Clay and Alachua/Gilchrist counties in Florida. In these counties, the effect of cotton dominance has much less of an impact on lynchings than the coefficient in Table 2 would indicate.

Of course, a thorough understanding of the reasons behind the weakened effect in these Florida counties would require more extensive investigation, but components of the spatial-effects model do suggest some potentially fruitful avenues to pursue. In particular, three conditions probably came together to produce this departure from the norm: (I) these three counties formed a distinct spatial cluster (at the turn of the century) in that they were closer to each other than to any other counties; (2) only one lynching occurred in this cluster of counties between 1895-1899; but (3) they are situated in an area of (north-central) Florida in which almost all of the lynchings in that state occurred. Apparently this lynching exposure overwhelmed the typical effect of cotton dominance in these counties because their location concentrated the spatial effect of high lynching incidents to their west. Hence, the cultural and economic explanations of lynchings cited above do not apply equally well to all counties and the spatial-effects model has "localized" our social history in a very important way.

\section{CONCLUDING REMARKS}

Social historians often study phenomena that take place in geographical space and current theorizing has put forth the objective of "localizing" social processes. There is a wide range of historical phenomena that allude to the operation of spatial processes. For instance, diffusion processes in social history are customarily invoked to explain the impact of population contact through disease transfer and the spread of technologies, information, attitudes, beliefs and behaviors. Historians have amassed ample theoretical and empirical literatures on the spread of epidemic disease in "virgin populations" and considerable effort has gone into tracking the geography of epidemics in Native American populations following European contact. More recent efforts have emphasized the spread of ideas and behaviors. The European fertility decline in the nineteenth century, the diffusion of religious group/church membership across the United States in the "Great Awakenings" of the eighteenth and nineteenth centuries and in the evangelical Protestantism movements in this century, and the rise in violent crime in the second half of the twentieth century have all been regarded as contagious social processes, yet "space" rarely enters historical discourse explicitly as an analytic construct. Spatial-effects models do exactly this.

In this paper we have reviewed the common conditions under which spatial dependence arises, explained a two-stage procedure through which 
spatial dependence can be detected and removed, offered simple visual displays of the spatial process and the unit-specific effects of independent variables in the presence of spatial effects, and offered two illustrations of spatial processes in historical research. These examples were selected because they summarize the intersection of spatial dynamics with direction of influence. In both examples, spatial processes are inferred, but their verification requires data beyond those available for these studies. Much greater detail (most important of which is the timing of events) about specific circumstances is required to make such a determination. If this auxiliary information is available, then the "event-structure analysis" described by Griffin in this volume is possibly a more appropriate methodology for this challenge than is the cross-sectional analysis explicated in this paper. ${ }^{40}$ However, additional evidence often is not available. In these circumstances it is reasonable to use the methods described in this essay to investigate the possibility that events occurring in different geographic areas are linked by more than mere coincidence, or by the fact that the locations share social conditions that help to determine the occurrence of those same events.

\section{ANNOTATED BIBLIOGRAPHY}

\section{The development of the two-stage estimation for spatial models}

The two-stage estimation method alluded to in this paper was developed (independently) by Luc Anselin and Kenneth Land. Their work is responsible for broadly expanding the application of spatial-effects models in the social sciences. The following publications give the technical details on model estimation:

Anselin, Luc, Spatial Econometrics: Methods and Models (Boston, 1988).

Land, Kenneth C. and Glenn Deane, "On the Estimation of Regression Models with Spatial Effects Terms for Large Samples: A Two-Stage Least Squares Approach", Sociological Methodology (Washington, DC, 1992), pp. 22I-248.

\section{Spatial-effects models applied in historical sociology/social history}

To our knowledge, the following articles are the only historical studies to date using spatial-effects models:

Blau, Judith R., Kenneth C. Land and Kent Redding, "The Expansion of Religious Affiliation: An Explanation of the Growth of Church Participation in the United States, I850-1930", Social Science Research, 2I (1992), pp. 329-352.

40. See also Larry J. Griffin, "Narrative, Event-Structure Analysis, and Causal Interpretation in Historical Sociology", American Journal of Sociology, 98 (1993), pp. 1094-I133. 
Land, Kenneth C., Glenn Deane and Judith R. Blau, " Religious Pluralism and Church Membership: A Spatial Diffusion Model", American Sociological Review, 56 (1992), pp. 237-249.

Tolnay, Stewart E., "The Spatial Diffusion of Fertility: A Cross-Sectional Analysis of Counties in the American South, 1940", American Sociological Review, 60 (1995), pp. 299-308.

Tolnay, Stewart E., Glenn Deane and E.M. Beck, "Vicarious Violence: Sparial Effects on Southern Lynchings, 1890-1919", American Journal of Sociology, 102 (1996), pp. 788-815.

\section{Spatial analysis: alternatives to the two-stage method of estimation}

The generation of spatial models described in this paper were formulated by Keith Ord, a geographer, in the early 1970 s and introduced into sociology by Patrick Doreian. A number of economists and regional scientists continue to develop spatial models using alternative methods to the twostage procedure we describe. Anselin's contributions, most recently in the area of "exploratory spatial data analysis", are the most notable and his SpaceStat software is the only statistical package written expressly for spatial data analysis.

Anselin, Luc, "Exploratory Spatial Data Analysis and Geographic Information Systems", in New Tools for Spatial Analysis (Luxembourg, 1994), pp. 45-54.

Anselin, Luc, SpaceStat Version 2.o., Bruton Center for Development Studies, University of Texas at Dallas, Dallas, TX (forthcoming, 1998).

Case, Anne C., "Spatial Patterns in Household Demand", Econometrica, 59 (I991), pp. 953-965.

Devine, Owen J., Thomas A. Louis and M. Elizabeth Halloran, "Identifying Areas with Elevated Disease Incidence Rates Using Empirical Bayes Estimators", Geographical Analysis, 28 (1996), pp. 187-199.

Doreian, Patrick, "Estimating Linear Models with Spatially Distributed Data”, in Sociological Methodology (San Francisco, 1980), pp. 359-388.

Kelejian Harry H., and Dennis P. Robinson, "A Suggested Method of Estimation for Spatial Interdependent Models with Autocorrelated Errors, and an Application to a County Expenditure Model", Papers in Regional Science, 72 (1993), pp. 297-312.

Ord, Keith, "Estimation Methods for Models of Spatial Interaction", Journal of the American Statistical Association, 70 (1975), pp. 120-126. 